\title{
Effects of Training on Organizational Performance
}

\author{
Cross Ogohi Daniel \\ Department of Business Administration, Nile University of Nigeria \\ Abuja, Nigeria \\ Email: danielcross [AT] nileuniversity.edu.ng
}

\begin{abstract}
Training is one of the Human Resources functions of the organization. When employees are recruited into the organization, they may not come with all the required skill set to discharge fully their roles in the organization. Hence, the one to equip such new employees with relevant skill set for the good of the organization. Also, the business world is very dynamic and ever changing. Organizations keep innovating making it imperative or organizations to keep training and learning. The rate technological advancement has made it almost impossible for any forward looking organization not to flow with the competition is cut throat. Customers keeping raising expectations which every bank which want to remain in business will necessarily have to meet. The Customer-facing employees will need the right skills, knowledge and attitude to manage the customers with their high expectation. The right skill, knowledge and attitude can be acquired through training. The research attempts to find out the impact which training has employee performance bearing in mind that the aggregate of individual performance will culminate to organizational performance. The study considered the microfinance bank sub-sector from which three banks were selected. Data was collected from 304 respondents who were drawn using Taro Yamane sample size determination technique through structured questionnaire. The data collected was subjected to both descriptive and inferential techniques were used to test formulated hypotheses. The study showed that employee skill, knowledge and ability gained from training has significant effect on productivity. Further findings reveal that training has effect on employee commitment to the organization. The conclusion is that training enhances employee performance as well as employee commitment to the organization. It is therefore, recommended that microfinance banks and all organization should take more active interest in the training of its employees.
\end{abstract}

Keywords - Training, Development, Organization and Performance

\section{INTRODUCTION}

Training is a necessity in the workplace. Without it, employees don't have a firm grasp on their responsibilities or duties. Employee training refers to programs that provide workers with information, new skills, or professional development opportunities. Training in Nigeria could be traced back to 1960 when it was discovered that most of the top government and business positions were occupied by expatriates (Olalere and Adesoji, 2013). The departure of the whites after independence gave rise to a big vacuum of capable indigenous human capital. This prompted the Federal Government of Nigeria to set up a Manpower Board in 1962 following the Ashby Commission's Recommendations (Olalere and Adesoji, 2013). Consequently, the Federal Government of Nigeria established complimentary institutions like the Centre for Management Development (CMD), Administrative Staff College of Nigeria, Industrial Training Fund (ITF), and Federal Training Centre to train and retrain employees as well as give orientation to fresh graduates of formal academic institutions (Olalere and Adesoji, 2013).

Training addresses gaps or discrepancies between an ideal and an optimal stage of development. However, from a comparison between desired and actual work methods or between desired and actual results, needs arise on the $\mathrm{j}$ ob. Smith and de Cronje (2010) refer to three methods for identifying needs: the generic methods, performance analysis, and competency assessment. Where performance analysis focuses on deficiencies or problems, competency assessment focuses on opportunity for improvement. Trainers identify how they believe people should perform and then design a training program to give the workers the skills they need.

Training can only be executed when it has been determined which employees should receive training and what their current levels, knowledge and skills are. Consequently, the assessment of the individual will indicate the range of skills and knowledge that is to be attained. Note that the difference between actual performance and required performance will ultimately form the training gap, and therefore indicate the extent of training needed. Training refers to linking the gap between the present performance and the standard desired performance. Training could be given via different methods such as on the coaching and mentoring, peer's cooperation and participation by the subordinates. 
Training is significant and an imperative tool for the organization to restore the performance of all the personnel for organizational growth and success. It is useful to both employers and employees of an organization. An employee will turn out to be more efficient and productive if he is trained well. Firms can create and enhance the quality of the present employees by providing widespread training and development. Training is important not only to expand productivity but also to motivate and inspire workers by allowing them know how essential their jobs are and providing them all the information they require to carry out those jobs (Anonymous, 1998). The general advantage received from employee training are: increased job satisfaction and increased motivation, morale, resulting in financial gain, increased efficiencies inn processes, increased capacity to adopt new technologies and methods, increased innovation in strategies and products and reduced employee turnover.

To contribute in the possible improvement of employee training in Microfinance Banks in general, this research was embarked upon to examine the effects of training on organizational performance vis-à-vis the processes of employee training and the challenges faced by the Human Resource Department in the selection of employees for training with reference to the employees of three selected Microfinance Banks in Abuja, Nigeria namely Hasal Microfinance Bank, Atlas Microfinance Bank and Fortis Microfinance Bank.

\section{STATEMENT OF THE PROBLEM}

This study begins from the realization of the need to effectively administer the effects of training on organizational performance. Training is a systematic process to enhance employee's skill, knowledge and competency, necessary to perform effectively on job. Overall, training impacts organizational competitiveness, revenue and performance. Unfortunately, the majority of governmental, private organization and international organizations are not recognizing the importance of training to increase their employee's productivity and when the economy slows or when profits decline, many organizations first seek cuts in their training budgets. This will leads to high job turnover then increase the cost to hire new employees which low down the organizational profitability.

The insights of employees on training have a great importance on the success of any organization. If the employees are pleased with the training policies of the organization, this will have a positive impact on the organization's productivity. The insights or attitude of employees is changed into positive or negative behavior. How do the employees view employee training policies of the organization? How does the Management view the Training Policy of its organization? Some view training and development as a waste of time and capital that would have been used in the production of goods and services that will increase profit to the organization. Sometimes, the concern that an employee could leave the organization after training affects the employees training and sometimes makes it unforeseen and unsystematic.

In order to fill this gap, the researcher is compelled to conduct a study on the effects of training on organizational performance with focus on processes and procedures of identifying skill gaps, training design and delivery style and employee perception towards training in Nigerian Microfinance Banks in Abuja.

\section{OBJECTIVES OF THE STUDY}

The main objective of the study is to investigate the impact of training on organizational performance with focus on three selected construction firms in Nigeria. However, specific objectives of the study are as follows:

i. To determine the extent of effect of training design on employee productivity;

ii. To determine the extent to which employee training affects organizational productivity.

\section{RESEARCH HYPOTHESES}

To achieve the objectives of this study, the following two null hypotheses were formulated for testing.

$\mathrm{H}_{1}$ : The extent to which training design affects organizational productivity is not significant.

$\mathrm{H}_{2}$ : The extent to which employee training affects organizational productivity is not significant

\section{LITERATURE REVIEW}

\subsection{Conceptual Framework}

There has been a general resistance to investment in training in organizations until recently because of the presumption that employees hired under a merit system are qualified and trained for their jobs (Okotoni and Erero, 2005). It was further assumed 
that if that was not the case then it means that initial selection of personnel was faulty (Hamid, 2011). This assumption no longer holds as the need for training became evident in all sectors (Okotoni and Erero, 2005).

According to Crawford in Adamu (2008), training is the ways in which specific knowledge and skills necessary to perform specific jobs are taught and learnt, development entails an analogous process in which people acquire more general abilities and information, but in ways that cannot always be tied directly to a particular task they perform. Training refers to the acquisition of skills, knowledge and information directly required for the performance of a specific role. It includes on-the-job training, workshops, seminars and conference. Development broadly refers to job enrichment that has an intrinsic mechanism to motivate an employee to accept and play challenging organizational tasks (Chukwunenye and Igbokwe, 2011).

Development is not as specific as training; it is more general in application. It is used in relation to the process of helping managerial employee who performs non-routine jobs to improve their managerial, administrative and decision making abilities and competence (Adamu, 2008).Training is any learning activity which is aimed at the acquisition of specific knowledge and skills for the purpose of an occupation or task.

"In the fast pace changing world of business and environmental uncertainty, organizations realize its limitation of dealing with new challenges (Tai, 2006). However the further states that the firms should invest in training programs to make their employees competent enough to face uncertainties and take effective decision in time, in order to remain competitive in the market. Effective training is beneficial for the firm in variety of ways, such as, it plays a vital role in building and maintaining capabilities, both on individual and organizational level, and thus participates in the process of organizational change (Ezigbo 2011). Moreover, it enhances the retention capacity of talented workforce, hence decreasing the unintentional job rotation of the workers (Jones and Wright, 1992; Shaw et al., 1998). Furthermore, it indicates the firm's long-term commitment towards its workers and increases the employee's motivational level (Pfeiffer, 1994). All these contributions lead to an achieving competitive advantage and to an enhancement in employee performance and organizational productivity (Huselid, 1995).Effective training and development programs aimed at improving the employees' performance. Training refers to bridging the gap between the current performance and the standard desired performance. Training could be given through different methods such as on the coaching and mentoring, peer's cooperation and participation by the subordinates. This team work enable employees to actively participate on the job and produces better performance, hence improving organizational performance.

Training programs not only develops employees but also help an organization to make best use of their humane resources in favor of gaining competitive advantage. Therefore, it seems mandatory by the firm to plan for such a training program for its employees to enhance their abilities and competencies that are needed at the workplace (Hamid, 2011).Training not only develops the capabilities of the employee but sharpen their thinking ability and creativity in order to take better decision in time and in more productive manner (Ezigbo, 2011). Moreover it also enables employees to deal with the customer in an effective manner and respond to their complaints in timely manner. Training develops self-efficacy and results in superior performance on job, by replacing the traditional weak practices by efficient and effective work related practices.

\subsection{Training Design and Organizational Performance}

It is very necessary for the organization to design training in a very careful manner (Armstrong, 2000). The design of the training should be according to the needs of the employees (Khan, Khan and Khan, 2011). Those organizations which develop a good training design according to the need of the employees as well as the organization always get good results (Partlow, 1996). Effective training design considers learning concepts, legal issues, and different approaches to training (Mathis and Jackson, 2000). Training design plays a very crucial role in the employee as well as organizational performance. A bad training design is nothing but the loss of time and money (Tsai and Lin, 2007).

Mathis and Jackson (2000) assert that there are three primary considerations when designing training. They are determining learner's readiness, understanding different learning styles, and designing training for transfer. For training to be successful and capable of influencing organizational performance, the trainees must have the basic skills necessary for learning, the motivation to learn and possess self-efficacy. Since the objective of training is to assist learners acquire the behavior necessary for effective work performance, it is therefore imperative that a clear understanding of the ways in which learning theories are applied when designing training programs are explained.

Flippo (1984) opines that the more highly motivated the trainee, the more quickly and thoroughly a new skill or knowledge is learned. People learn if they accept the need for training and commit to it. For instance, if their motivation is weak and they doubt their ability to learn; no matter how well their training is designed and implemented, its effectiveness will be limited. This is to say that training must be related to something which the trainee desires. The drive could be the need which the trainee feels that training will help him or her solve. For example, job promotion, recognition, and so on (Bryan, 1990). 
The second requirement is cue. Through training the learner recognizes relevant cues and associates them with desired responses. The third is response. Training should be immediately followed with positive reinforcement to enable the learner feel the response. If reinforcement is not timely, positive and consistent; then there is every tendency that it will not produce the desired result. Feedback is another important requirement. The information the learner receives indicating the quality of his response is the feedback. It should be made available as quickly as possible to ensure possible effective learning. Although, these learning principles are good, the author, nevertheless, failed to discuss its practicability, where the learner actively participates in using the skills and knowledge acquired and did not mention that the level of aptitude and intelligence of individuals are different and that could affect the methods of training (Bryan, 1990).

\subsection{Effects of Employee Training on Employee Motivation Vis-À-Vis Organizational Performance}

Stoner, Freeman and Gilbert (2007) affirm that "managers and management researchers have long believed that organizational goals are unattainable without the enduring commitment of members of the organization". There will be no improvement on employees' performance without employees being motivated to perform. Several authors have given many definitions to motivation. However, a general understanding from the various definitions of Motivation is that motivation is what causes one to act (Stoner et al, 2007). It is the process that guides and maintains goal-oriented behavior. Motivation is a human psychological characteristic that contributes to a person's degree of commitment. Eisenhower defined "Motivation as the art of getting people to do what you want them to do because they want to do it" (Brainy Quote).

Training is an excellent source of motivation. When an organization sends an employee for training, obviously, that employee will be motivated to perform. Advance Team Concepts, a training firm based in the USA opine that trained employees have a greater capacity to be empowered and perform with excellence, which also motivates them since it builds their sense of ownership, confidence and willingness. No matter the size of an organization, having a team of motivated, hardworking employee is crucial to business success.

Similarly, when people lose their motivation, their productivity suffers. They become less productive, less creative; less of an asset to the organization (AllBusiness.com).Training has always been seen as a positive impact in every organization. Employee training increases employee motivation to perform which in-turn increases organizational performance. Looking back to the original experiment by Elton Mayo in Chicago from 1927 - 1932, the mere fact that an organization has paid attention to people (employee) spurs them to better job performance.

For instance, suppose a management trainee has been given specialized training in skills show that such employee is valued in the organization. The feeling that he/she is on track to the top will motivate him/her to work harder and better. From the argument thus far, training has an important role in motivating employee to increased performance. Besides, employees need to be constantly motivated to ensure that there is no shortfall in productivity.

\subsection{Measuring the Impact of Training on Organizational Performance}

valuating the impact of investments in people (such as training) helps to justify the costs incurred, validate the intervention as a business tool, and aid the design and selection of future investment methods (Page, Jagger, Tamkin and Henwood, 2006). Page et al (2006) further assert that in practical terms, isolating the impact on the bottom line is complex and therefore many organizations do not try to measure it very rigorously. Evaluation is a systematic process of determining the significance or worth of subject, using criteria governed by a set of standards. It can assist an organization to ascertain the degree of achievement or value in regards to the aim and objectives of an undertaken project.

The primary aim of evaluation, apart from gaining insight into prior or existing initiatives, is to enable reflection and assistance in the identification of future change (Sarah Del Tufo, 2002)

i. Organizational Performance Measurement

Many measures of performance may be more relevant to some sectors than others. When measuring organizational performance, the choice of measures should be informed by the sector and business-specific context (Page et al, 2006). Measurement of organizational performance is not without its challenges. Measures based on accountancy are to some extent, open to manipulation and therefore may be difficult to compare over time, or between organizations. Many measures do not necessarily capture the quality of a product or service and where part-time work is frequent and to be comparable, measures need to take into account hours worked (Page et al, 2006).

Page and others developed a set of 'core' measures of organizational performance that have general application, to enable benchmarking and comparison across sectors. The 'core' set of measures include: 
a. Productivity: Productivity could be measured using Net added value per hour worked or Net added value per worker. However, this measure will be affected by investments other than those in skills and training, for example in capital

b. Profitability: Return on assets is a useful measure of profitability, and measures how well a company is using its assets to generate earnings. However, values can vary substantially between companies and between sectors and therefore for wider benchmarking purposes profit per employee may be more effective.

c. Quality: Manufacturing organizations could estimate quality using the Number of defects in a given number of products. More generally, customer satisfaction could be used. Exactly how customer satisfaction is measured is likely to vary from organization to organization.

d. Innovation: Sales (N) from new or adapted products or services is a measure that could be used to benchmark innovation across sectors and which takes some account of the success of the innovation

e. Staff performance: Employees' performance is appraised against preset standards.

\section{ii. Employee Performance Indicators}

Tracking employee training and measuring training effectiveness is a key objective of any HR department. To ensure that there is adequate return on investment in training of new and current employees, the organization has to establish key performance indicators (KPI). KPI if created and tracked properly serve as a benchmark for measuring the progress of employees towards a set of broader based goals or objectives (Lilly, 2011). However, most organizations are faced with the challenges of developing a good KPI.

Lilly (2011) suggests that quality key performance indicators for tracking employee training effectiveness should include: Measurable and quantifiable indicators; Competency based indicators; Linked to proficiency indicators; and Mapped to organizational and employee goals indicators. Hakala (2008) explains that performance measurement uses the following indicators of performance

a. Quantity: This indicator places emphasis on the number of units produced processed or sold against the set standard i.e. the number of units to be produced, processed or sold

b. Quality: The quality of work performed can be measured by several means. The percentage of work output that must be redone or is rejected is one such indicator. In a sales environment, the percentage of inquiries converted to sales is an indicator of salesmanship quality.

c. Timeliness: This indicator measures how fast work is performed or how fast services are provided. For example, in a service industry, the average customer's downtime is a good indicator of timeliness, while in a manufacturing outfit; it might be the number of units produced per hour.

d. Cost-Effectiveness: The cost of work performed should be used as a measure of performance only if the employee has some degree of control over costs.

e. Absenteeism/Tardiness: An employee is obviously not performing when he or she is not at work. Other employees' performance may be adversely impacted by absences, too.

f. Creativity: It can be difficult to quantify creativity as a performance indicator, but in many white-collar jobs, it is vitally important. Supervisors and employees should keep track of creative work examples and attempt to quantify them.

g. Adherence to Policy: This may seem to be the opposite of creativity, but it is merely a boundary on creativity. Deviations from policy indicate an employee whose performance goals are not well aligned with those of the company.

h. Gossip and Other Personal Habits: This indicator may not seem performance-related to the employee, but some personal habits, like gossip, can detract from job performance and interfere with the performance of others. The specific behaviors should be defined, and goals should be set for reducing their frequency.

i. Personal Appearance/Grooming: Most people know how to dress for work, but in many organizations, there is at least one employee who needs to be told.

\section{METHODOLOGY}

This research therefore covers the selected Coca-Cola Bottling Company in Abuja. Secondary data were obtained through books, journals, and internet. Empirical works of other scholars were consulted. A simple size of 319 was obtained from the population of 1573 at 5\% error tolerance and 95\% degree of freedom using Yamane's statistical formula 304(95.3\%) of the questionnaires distributed 151(71\%) were returned and 15(4.7\%) were not returned. The questionnaire was designed in Likert scale format. The researchers conducted a pre-test on the questionnaire to ensure the validity of the instrument. Simple linear regression test and Pearson product moment correlation coefficient were used to test the hypotheses. 


\section{TEST OF HYPOTHESES}

The two hypotheses were tested with various test statistics aided by computer applied Statistical Package for Social Sciences (SPSS: 21.00s version) of Microsoft environment. Specifically, Pearson product moment correlation coefficient test was used to test hypotheses one and, hypothesis two was tested using simple linear regression

\section{Test of hypothesis one}

$\mathrm{H}_{1}$ : The extent to which training design affects organizational productivity is not significant.

Table 1: Descriptive Statistics

\begin{tabular}{|l|r|r|r|}
\hline & Mean & $\begin{array}{c}\text { Std. } \\
\text { Deviation }\end{array}$ & $\mathrm{N}$ \\
\hline $\begin{array}{c}\text { organizational } \\
\text { productivity }\end{array}$ & 2.8253 & 1.27682 & 304 \\
Training Design & 3.1613 & 1.37593 & 304 \\
\hline
\end{tabular}

Source: SPSS version 21.00

Table 2: Correlations

\begin{tabular}{|lc|c|c|}
\hline & $\begin{array}{c}\text { Training } \\
\text { Design }\end{array}$ & $\begin{array}{c}\text { organizational } \\
\text { productivity }\end{array}$ \\
\hline $\begin{array}{c}\text { organizational } \\
\text { productivity }\end{array}$ & $\begin{array}{c}\text { Pearson } \\
\text { Correlation }\end{array}$ & 1 & $.716\left(^{* *}\right)$ \\
& Sig. (2-tailed) & & .000 \\
Training Design & $\mathrm{N}$ & 304 & 304 \\
& Pearson & $.716\left(^{* *}\right)$ & 1 \\
& Correlation & .000 & \\
& Sig. (2-tailed) & 304 & 304 \\
\hline
\end{tabular}

** Correlation is significant at the 0.01 level (2-tailed). Source: SPSS version 21.00

Table (1) shows the descriptive statistics of the Organizational Productivity via, Training Design with a mean response of 2.8253 and std. deviation of 1.27682 for Training Design and a mean response of 3.1613 and std. deviation of 1.37593 for organizational productivity and number of respondents (304). By careful observation of standard deviation values, there is not much difference in terms of the standard deviation scores. This implies that there is about the same variability of data points between the dependent and independent variables.

Table (2) is the Pearson correlation coefficient for Training Design and organizational Productivity. The correlation coefficient shows 0.716 . This value indicates that correlation is significant at 0.05 level (2tailed) and implies that there is a significant positive relationship between Training Design and organizational productivity $(r=.716)$. The computed correlations coefficient is greater than the table value of $r=.195$ with 383 degrees of freedom $(\mathrm{df} .=\mathrm{n}-2)$ at alpha level for a two-tailed test $(\mathrm{r}=.716, \mathrm{p}<.05)$. However, since the computed $\mathrm{r}=.716$, is greater than the table value of .195 we reject the null hypothesis and conclude that the extent to which training design affects organizational productivity is significant $(\mathrm{r}=.716$, $\mathrm{P}<.05)$. 


\section{Test of Hypothesis Two}

$\mathrm{H}_{2}$ : The extent to which employee training affects organizational productivity is not significant

Table 3: Descriptive Statistics

\begin{tabular}{|l|c|c|c|}
\hline & Mean & $\begin{array}{c}\text { Std. } \\
\text { Deviation }\end{array}$ & N \\
\hline Training Design & 1.7532 & .95348 & 608 \\
$\begin{array}{l}\text { Organizational } \\
\text { productivity }\end{array}$ & 1.9948 & .64304 & 608 \\
\hline
\end{tabular}

Table 4: Model Summary ${ }^{\mathrm{a}}$

\begin{tabular}{|c|c|c|c|}
\hline & & $\begin{array}{l}\text { Training } \\
\text { Design }\end{array}$ & $\begin{array}{l}\text { organizational } \\
\text { productivity }\end{array}$ \\
\hline $\begin{array}{c}\text { Pearson } \\
\text { Correlation }\end{array}$ & Training Design & 1.000 & .808 \\
\cline { 2 - 4 } & $\begin{array}{c}\text { organizational } \\
\text { productivity }\end{array}$ & .808 & 1.000 \\
\hline \multirow{2}{*}{ Sig. (1-tailed) } & Training Design &. & .000 \\
\cline { 2 - 4 } & $\begin{array}{c}\text { organizational } \\
\text { productivity }\end{array}$ & .000 &. \\
\hline \multirow{2}{*}{$\mathrm{N}$} & $\begin{array}{c}\text { Training Design } \\
\text { organizational }\end{array}$ & 608 & 608 \\
\cline { 2 - 4 } & $\begin{array}{c}\text { oroductivity } \\
\text { pros }\end{array}$ & 608 \\
\hline
\end{tabular}

Table 5: Model Summary ${ }^{b}$

\begin{tabular}{|l|c|c|c|c|c|}
\hline Model & $\mathrm{R}$ & $\begin{array}{c}\mathrm{R} \\
\text { Square }\end{array}$ & $\begin{array}{c}\text { Adjusted } \mathrm{R} \\
\text { Square }\end{array}$ & $\begin{array}{c}\text { Std. Error of } \\
\text { the Estimate }\end{array}$ & $\begin{array}{c}\text { Durbin- } \\
\text { Watson }\end{array}$ \\
\hline 1 & $.808^{\mathrm{a}}$ & .795 & .693 & .90787 & .044 \\
\hline \multicolumn{6}{|l}{} \\
\hline
\end{tabular}


Table 6: Coefficients ${ }^{\mathrm{a}}$

\begin{tabular}{|c|c|c|c|c|c|}
\hline \multirow{2}{*}{\multicolumn{2}{|c|}{ Model }} & \multicolumn{2}{|c|}{ Unstandardized Coefficients } & \multirow{2}{*}{$\begin{array}{c}\begin{array}{c}\text { Standardized } \\
\text { Coefficients }\end{array} \\
\text { Beta }\end{array}$} & \multirow[b]{2}{*}{$\mathrm{T}$} \\
\hline & & B & Std. Error & & \\
\hline 1 & (Constant) & 2.663 & .107 & & 24.956 \\
\hline & $\begin{array}{l}\text { Training } \\
\text { Design }\end{array}$ & 1.456 & .051 & .808 & 18.956 \\
\hline
\end{tabular}

a. Dependent Variable: organizational productivity

Table 7: ANOVA ${ }^{\mathrm{b}}$

\begin{tabular}{|l|c|c|c|c|c|c|}
\hline \multicolumn{2}{|l|}{} & \multicolumn{1}{c|}{$\begin{array}{c}\text { Sum } \\
\text { Squares }\end{array}$} & of & $\begin{array}{c}\text { Mean } \\
\text { Square }\end{array}$ & F & Sig. \\
\hline \multirow{2}{*}{1} & Regressio & 66.109 & 1 & 66.109 & 80.207 & $.000^{\mathrm{a}}$ \\
\cline { 2 - 8 } & Residual & 633.008 & 606 & .824 & & \\
\cline { 2 - 8 } & Total & 699.117 & 607 & & & \\
\hline
\end{tabular}

$$
\begin{aligned}
& \mathrm{R}=0.808 \\
& \mathrm{R}^{2}=0.795 \\
& \mathrm{~F}=80.207 \\
& \mathrm{DW}=.044
\end{aligned}
$$

\section{Interpretation:}

The regression sum of squares (66.109) is less than the residual sum of squares (633.008), which indicates that more of the variation in the dependent variable is not explained by the model. The significance value of the F statistics (0.000) is less than 0.05 , which means that the variation explained by the model is not due to chance.

$\mathrm{R}$, the correlation coefficient which has a value of 0.808 , indicates that extent to which employee training affects organizational productivity is significant. R square, the coefficient of determination, shows that $79.5 \%$ of the variation in the customer satisfaction is explained by the model.

With the linear regression model, the error of estimate is high, with a value of about 0.90787 . The Durbin Watson statistics of .044, which is not tends to 2 indicates there no is autocorrelation. The Training Design coefficient of 0.513 indicates a positive significance between Training Design and organizational productivity, which is statistically significant (with $t=$ 24.956). Therefore, the null hypothesis should be rejected and the alternate hypothesis accordingly accepted.

\section{DISCUSSION OF FINDINGS}

Hypothesis one was tested with Pearson's product moment correlation in order determine the extent of effect of training design on employee productivity, with a computed result $(\mathrm{r}=0.716 ; \mathrm{p}<0.05)$, the null hypothesis was rejected and the 
alternate hypothesis was accepted resulting in the conclusion that the extent to which training design affects organizational productivity is significant.

Hypothesis two was tested using simple linear regression to determine the extent to which employee training affects organizational productivity, with a computed result $(\mathrm{r}=0.808 ; \mathrm{F} 80.207 ; \mathrm{t}=24.956 ; \mathrm{P}<0.05)$. The null hypothesis was rejected and the alternate hypothesis was accepted resulting in the conclusion that extent to which employee training affects organizational productivity is not significant

\section{CONCLUSION}

Conclusively, the result of this study has shown that training influences organizational Productivity in the microfinance banks. Specifically, with consistent training, skill, knowledge and ability of employees in microfinance banks are bound to improve. Consequently, the trained employees will apply this skill, knowledge and ability to improve productivity, efficiency and commitment and therefore render quality services to customers of the organisations. The business environment is constantly evolving and dynamic; therefore there is no gainsaying to the fact that any future inclined organisation like most microfinance banks must prioritise training so as to effectively improve its employees' performance.

\section{RECOMMENDATIONS}

From the research findings, it is very clear that training an important critical survival and success factor for the organization. It is therefore imperative that the organization should pay the deserved attention to training. In view of, the following recommendations are put forward:

i. Top Management Support: The top management of the organization should recognize training as critical to the success of the organization and impress on other level of employees to do the same. In this regard, top management should not secret of its support for training. Training should not be seen as a means of distributing favor and loyalty patronage to employees. It is in the interest of the organization for the employees to be trained adequately for the challenges of their job roles.

ii. Attitude towards training: Some employees see training as a period of jamboree when they can be away from office routine and have fun, without minding the cost in terms time and financial resources to the organization. Organization pays for the training but the employee hardly attends the training thereby denying the organization the benefit of the training. Employees need to show the right attitude towards training to encourage the organization to keep training. Sometimes management sees training as waste of money and time because staff could still function without getting formal training. Training enhances employee commitment to the organization and employee commitment is invaluable in an organization.

iii. Proper organizational needs assessment: Through appraisal process, the organizational and individual training needs can be established. Due to the high cost of training, it should not be handled on a haphazard manner.

\section{REFERENCES}

[1] Adamu, S. (2008), Manpower Planning and Administration, Lagos: National Open University of Nigeria.

[2] Anonymous (1998, Sept/Oct). What nonprofits need to know about technology. Nonprofit World, 16, 38.

[3] Armstrong, M. (1996), A Handbook on Personnel Management Practice, (5th edition), London: Kogan Page.

[4] Brainy Quote, www.brainyquote.com, [accessed 25 August 2018].

[5] Bryan, L. A. (1990), An Ounce of Prevention for Workplace Accidents, Training and Development Journal, 44(7), NY: USA.

[6] Chukwunenye, I.O., and Igbokwe, B.N. (June, 2011), Training, manpower development and job performance: perception and relevance among civil servants in Ebonyi State, Nigeria. Journal of Economics and International Finance, 3(6), 399-406, http://www.academicjournals.org/JEIF [accessed 3 September 2018].

[7] Ezigbo, C.A. (2011), Advanced Management: Theory and Applications, Enugu: Immaculate Publications Limited.

[8] Flippo, E.R. (1984), Personnel Management (6th Ed), New York: McGraw-Hill.

[9] Hakala, D. (2008), 16 Ways to Measure Employee Performance. HR World, http://www.hrworld.com/features/16-waysmeasure-performance-021908, [accessed 23 July 2018]. 
[10] Hamid, S. (2011), A study of effectiveness of training and development programmes of UPSTDG, India - An Analysis, South

[11] Huselid, M.A. (1995), "The impact of human resource management practices on turnover, productivity and corporate financial performance",Academy of Management Journal, Vol. 38 No. 3, pp. 635-72.

[12] Khan, R.A.G., Khan, F.A. and Khan, M.A. (July, 2011), Impact of Training and Development on Organizational Performance, Global Journal of Management and Business Research, 11(7). Global Journals Inc. (USA). http://globaljournals.org/GJMBR_Volume11/8-Impact-of-Training-and-Developmenton- $\quad$ OrganizationalPerformance.pdf \{accessed 3 September, 2018]

[13] Lilly, A.J. (2011), Tracking Employee Training: Measuring training effectiveness with KPIs, Robert Bacal/Bacal \& Associates. Canada: Casselman, www.thetrainingworld.com/articles/kpi.htm. [accessed 12 May 2018].

[14] Mathis, R.L. and Jackson, J.H. (2004), Human Resource Management (10th ed), Singapore: South-Western.

[15] Okotoni, O. and Erero, J. (Jan., 2005), Manpower training and development in the Nigerian public service, African Journal of Public Administration and Management (AJPAM 16(1)).

[16] Olalere, T.O. and Adesoji, A.A. (May, 2013), Human Capital Development in First Bank of Nigeria Plc, Mediterranean Journal of Social Science 4(2). MCSER-CEMAS-Sapienza University of Rome.

[17] Page R, Jagger N, Tamkin P, Henwood N. (2006), The Measurement of Organizational Performance, Research Report, Sector Skills Development Agency, http://www.employment-studies.co.uk/pubs/summary.php?id=ssda0513, [accessed 11

[18] Pfeiffer, J. (1994),Competitive Advantage through People, Harvard Business School Press, Boston, MA

[19] Sarah del Tufo (2002), "What is evaluation?" Evaluation Trust, The Evaluation Trust, http://www.evaluationtrust.org/evaluation/evaluate, [accessed 22 May 2018].

[20] Smith, G, De Cronje H. (2010), How to Increase Job Satisfaction and Improve Employee Engagement, www.chartcourse.com/articlepride.htm.

[21] Stoner, J.A.F., Freeman, R.E and Gilbert, D.R. (2007), Management (6th ed). Dehli, India: Dorling Kindersley (India) Pvt. Ltd.

[22] Tamkin, P. (2005), The contribution of skills to Business Performance, UK: Institute for Employment Studies (IES)

[23] Tai, W. T., (2006). Effects of Training Framing, General Self-efficacy and Training Motivation on Trainees' Training Effectiveness, Emerald Group Publishers, 35(1), pp. 51-65.

[24] Tsai, S.H. and Lin, Y.C. (2007), "Promoting service quality in tourist hotels: the role of HRM practices and service behavior", Tourism Management, 25, pp.471-482 